University of Nebraska - Lincoln

DigitalCommons@University of Nebraska - Lincoln

USDA National Wildlife Research Center - Staff Publications
U.S. Department of Agriculture: Animal and Plant Health Inspection Service

2020

\title{
Predator scent and visual cue applied to nest boxes fail to dissuade European Starlings (Sturnus vulgaris) from nesting
}

\author{
Bradley Blackwell \\ USDA APHIS Wildlife Services, bradley.f.blackwell@aphis.usda.gov \\ Thomas W. Seamans \\ USDA APHIS Wildlife Services, thomas.w.seamans@aphis.usda.gov \\ Morgan Pfeiffer \\ USDA APHIS Wildlife Services, morgan.b.pfeiffer@usda.gov \\ Bruce N. Buckingham \\ USDA APHIS Wildlife Services
}

Follow this and additional works at: https://digitalcommons.unl.edu/icwdm_usdanwrc

Part of the Natural Resources and Conservation Commons, Natural Resources Management and Policy Commons, Other Environmental Sciences Commons, Other Veterinary Medicine Commons, Population Biology Commons, Terrestrial and Aquatic Ecology Commons, Veterinary Infectious Diseases Commons, Veterinary Microbiology and Immunobiology Commons, Veterinary Preventive Medicine, Epidemiology, and Public Health Commons, and the Zoology Commons

Blackwell, Bradley; Seamans, Thomas W.; Pfeiffer, Morgan; and Buckingham, Bruce N., "Predator scent and visual cue applied to nest boxes fail to dissuade European Starlings (Sturnus vulgaris) from nesting" (2020). USDA National Wildlife Research Center - Staff Publications. 2363.

https://digitalcommons.unl.edu/icwdm_usdanwrc/2363

This Article is brought to you for free and open access by the U.S. Department of Agriculture: Animal and Plant Health Inspection Service at DigitalCommons@University of Nebraska - Lincoln. It has been accepted for inclusion in USDA National Wildlife Research Center - Staff Publications by an authorized administrator of DigitalCommons@University of Nebraska - Lincoln. 


\title{
Predator scent and visual cue applied to nest boxes fail to dissuade European Starlings (Sturnus vulgaris) from nesting
}

\author{
Bradley F. Blackwell, ${ }^{1 *}$ Thomas W. Seamans, ${ }^{1}$ Morgan B. Pfeiffer, ${ }^{1,2}$ and Bruce N. Buckingham ${ }^{1}$
}

ABSTRACT - Indirect predator cues have been shown to enhance perceived nest predation risk in both open-cup and cavity-nesting birds. We hypothesized that scent from the raccoon (Procyon lotor) inside nest boxes, supplemented with raccoon hair as a visual cue on the outside of the box, would enhance perceived risk to the European Starling (Sturnus vulgaris), resulting in reduced use of treated nest boxes and negative effects on reproduction. The starling is recognized, outside its native range, as a competitor with indigenous cavity nesters and a pest species, and efforts to deter its nesting have generally been unsuccessful. Our objectives were to examine nest initiation, clutch development, and hatching success by starlings relative to 4 nest box treatments. Starlings selected from nest boxes treated with a novel visual cue at the entry hole, predator scent inside the nest box and supplemented with a predator visual cue at the entry hole, the predator visual cue, or a novel odor inside the box and supplemented with the novel visual cue at the entry hole ( $n=120$ boxes; $n=30$ per treatment). Starlings established nest bowls in $65 \%$ of nest boxes (novel visual cue $=21$ boxes, predator scent/predator visual cue $=19$ boxes, predator visual cue $=17$ boxes, novel odor/novel visual cue $=21$ boxes); clutches $(\geq 1$ egg) were laid in 80 boxes, but 2 boxes contained a single egg with no nest. We observed no effects of treatment on likelihood of starlings laying a clutch, date of first egg, clutch size, or hatchling number. We conclude that raccoon scent inside nest boxes, supplemented by raccoon hair as a visual cue, failed to enhance perceived risk to starlings such that nesting was deterred. We suggest that direct or indirect experience with nest predation attempts (which enhance perceived risk) and the starling's plasticity in antipredator responses are key hurdles in development of an efficacious nesting deterrent. Therefore, we encourage the evaluation of direct predation risk via use of predator effigies on or in nest boxes, as well as in foraging areas proximate to nest boxes. Received 14 March 2019. Accepted 2 April 2020.

Key words: antipredator behavior, cavity-nesting birds, olfactory cue, predation risk, Procyon lotor

\section{La aplicación de olor y señal visual de depredador en cajas-nido no sirven para disuadir la anidación de los estorninos Sturnus vulgaris}

RESUMEN (Spanish)—Se ha demostrado que las señales indirectas de depredadores aumentan la percepción del riesgo de depredación en aves con nidos de copa abierta y aquellas que anidan en cavidades. Sometimos a prueba nuestra hipótesis de que el olor del mapache (Procyon lotor) en el interior de las cajas-nido, adicionado con pelo de mapache como señal visual fuera de la caja-nido, aumentaría la percepción de riesgo para el estornino Sturnus vulgaris, teniendo como resultado un uso reducido de las cajas-nido tratadas y efectos negativos en su reproducción. Fuera de su rango nativo de distribución, el estornino es reconocido como un competidor con aves locales que anidan en cavidades y como una plaga, y los esfuerzos para detener su anidación generalmente han fracasado. Nuestros objetivos fueron examinar el inicio del nido, desarrollo de la puesta y éxito de eclosión en relación a 4 tratamientos de caja-nido. Los estorninos eligieron entre cajas-nido tratadas con una señal visual nueva en el agujero de entrada, con olor de depredador dentro de la caja-nido y suplementada con una señal visual en el agujero de entrada, con señal visual del depredador o con un olor nuevo dentro de la caja suplementada con la señal visual en el agujero de entrada $(n=120$ cajas; $n=30$ por tratamiento). Los estorninos establecieron nidos en el $65 \%$ de las cajas-nido (con la señal visual nueva $=21$ cajas, con olor y señal visual nueva de depredador $=19$ cajas, con señal visual de depredador $=17$ cajas, y con olor nuevo y señal visual nueva $=21$ cajas). Hicieron puestas $(\geq 1$ huevo) en 80 cajas, si bien 2 de éstas contenían un único huevo sin nido. No observamos efectos del tratamiento en la probabilidad de que los estorninos hicieran una puesta, en la fecha del primer huevo, tamaño de puesta o número de polluelos. Concluimos que el olor del mapache en el interior de las cajas-nido, suplementado con pelo de mapache como señal visual, no aumentan el riesgo percibido por los estorninos al grado de disuadir su anidación. Sugerimos que la experiencia directa o indirecta con intentos de depredación de nidos (que aumentan el riesgo percibido), y la plasticidad del estornino en su respuesta antidepredador, son obstáculos clave en el desarrollo de un desalentador de anidación. Por ello, proponemos la evaluación de riesgo directo de depredación por medio de efigies de depredadores sobre o dentro de las cajas nido, así como en áreas de forrajeo cercanas a cajas-nido.

Palabras clave: aves que anidan en cavidades, comportamiento antidepredador, pista olfativa, Procyon lotor, riesgo de depredación

The success of invasive species and so-called "urban adaptor" species in new areas is typically

${ }^{1}$ U.S. Department of Agriculture, Animal and Plant Health Inspection Service, Wildlife Services, National Wildlife Research Center, Ohio Field Station, Sandusky, $\mathrm{OH}$, USA

${ }^{2}$ School of Natural Resource Management, Nelson Mandela Metropolitan University, George Campus, George, Western Cape Province, South Africa

* Corresponding author: bradley.f.blackwell@usda.gov characterized by some combination of behavioral plasticity in diet and habitat requirements, bold or aggressive exploration of new habitats, high adult survival, relatively high fecundity, and plasticity in antipredator behavior (Lodge 1993, Sih et al. 2004, Lowry et al. 2013, Castorani and Hovel 2016). The European Starling (Sturnus vulgaris; hereafter, starling) is an apt example of a successful species in its invasion of new habitats 
(Feare 1984). Originally from western Eurasia, the starling was introduced to the United States in the 1890s and, since, has expanded its distribution to include much of North America (Chapman 1925, Kessel 1957, Linz et al. 2007) as well as South Africa (Winterbottom and Liversidge 1954), Australasia, Pacific and Caribbean islands (Feare 1984), and South America (Pérez 1988, Zufiaurre et al. 2016). The starling's success is underscored by similar characteristics as those noted above, particularly its generalist ecological requirements (Kessell 1957) and ability to live near and benefit from humans (Crick et al. 2002, Mennechez and Clergeau 2006).

Subsequent to its introduction to the USA, the starling became a competitive threat to indigenous cavity-nesting birds (Kalmbach and Gabrielson 1921, Brush 1983, Kerpez and Smith 1990, Cabe 1993, Ingold 1994; but see Koenig 2003, Koenig et al. 2017) and was regarded as a pest species (Feare 1984, Pimentel et al. 2000, Linz et al. 2007, Lewis and Conover 2018) and an aviation-safety concern (DeVault et al. 2011, 2018; Dolbeer and Begier 2019). Further, the starling makes use of a variety of nest sites including human structures (Kessell 1957, Feare 1984) and vehicles (Bridgman 1962, Jackson 2000). As such, safety issues posed to aviation are not simply due to starlingaircraft collisions (Dolbeer and Begier 2019) but also the introduction of foreign object debris into aircraft engines and control surfaces (Bridgman 1962, Jackson 2000).

Efforts to identify means to deter starling nesting, in addition to exclusion, harken back over 3 decades in the USA, but have largely proven ineffective (Seamans et al. 2015). This lack of success in deterring starling nesting is not necessarily surprising, as perceived risk is a component of nest-site selection (Hua et al. 2013). Risk comprises temporal and spatial components (Lima 2009, Moks et al. 2016), and cavity-nesting species generally experience low nest predation (Nice 1957, Martin 1993, Fontaine et al. 2007; see also Mouton and Martin 2018). Cavity dimensions and availability of natural cavities play a role in nest-site selection by starlings (Aitken and Martin 2008, Tyson et al. 2011, Seamans et al. 2015), and these factors, along with predation risk, likely influence starling use of anthropogenic structures, as well as engines and flight surfaces on aircraft. However, with the exception of covers for engine openings, physically excluding starlings from aircraft flight surfaces and hangars is not necessarily feasible.

Recently, we tested the hypothesis that indirect predator sign in a nest box (an olfactory cue) would enhance perceived risk to adult starlings, thus affecting reduced use of treated sites (i.e., exposure of adults to predation mortality) and reduced reproduction (Blackwell et al. 2018). We based our hypothesis on the fact that antipredator behavioral responses to predation risk during nesting, as well as in other contexts, can involve multiple sensory cues beyond the temporality of actual predation events (Kats and Dill 1998, Lima 1998, Lima and Bednekoff 1999). For instance, predator scent can negatively affect prey activity level, suppress nondefensive behaviors such as foraging, feeding, and preening, and stimulate shifts to habitats perceived to be less risky (Kats and Dill 1998, Apfelbach et al. 2005, Roth et al. 2008, Lloyd et al. 2009, Parsons and Blumstein 2010, Hegab et al. 2015). Further, there is ample evidence that birds have a highly developed olfactory sense (Clark and Mason 1987, Amo et al. 2008, 2011, 2017; DeGroof et al. 2010, Avilés and Amo 2018), and recent findings confirm antipredator response by nesting birds, including cavity-nesting species, to the presence of mammalian predator scent near or in potential nest sites (e.g., Amo et al. 2008, 2011; Mönkkönen et al. 2009, Forsman et al. 2013, Stanbury and Briskie 2015).

In our recent effort we found no effect of scent from a known, North American predator of cavity nests (including those of starlings), the raccoon (Procyon lotor), on timing of starling nest initiation, clutch size, or number of hatchlings (Blackwell et al. 2018). We concluded that starlings using nest boxes on our study site had little to no direct experience with a predation attempt by a raccoon (because of predator guards used below nest boxes during experiments; see Seamans et al. 2015). Prior experience with a particular nest predator can serve to enhance perceived risk associated with a predator scent cue (Godard et al. 2007). That said, previous research focused on starling use of nest boxes at the same research area noted in Blackwell et al. (2018) has, absent predator guards, been disrupted by raccoon nest predation (Dolbeer et al. 1988; TWS pers. obs.). 
Further, we (Blackwell et al. 2018) suggested that future research should assess starling response to a combination of indirect predator cues, including olfactory and visual treatments, (sensu Mönkkönen et al. 2009; see also Amo et al. 2008). Therefore, as an extension of this previous research, our purpose was to investigate the response of starlings to the presence of not only mammalian predator scent inside nest boxes, but also scent supplemented by a predator visual cue associated with nest boxes. We were also interested in the possibility of subsequent development of a relatively easy-to-use starling nesting deterrent. Here, we considered the practical perspective of potential applications of our findings. Specifically, when considering potential efficacy of candidate nesting deterrents for use in aircraft hangars or on aircraft, actual predation events that might enhance perceived risk in these contexts are likely rare relative to those experienced by starlings nesting in tree cavities.

As in Blackwell et al. (2018), we hypothesized that indirect predator sign in or on a nest box would impose both perceived risk to adults and potential offspring, thus affecting use of the site (i.e., exposure of the adults; Lima and Dill 1990, Lima 2009, Hua et al. 2014), and aspects of reproduction (i.e., exposure of potential offspring; Martin and Briskie 2009). We predicted that (1) starlings would avoid nest boxes pretreated with a predator scent supplemented with a predator visual cue, but readily nest in other boxes; and (2) alternatively, if starlings nested in boxes treated with predator scent supplemented with the predator visual cue, nest initiation would be delayed, and clutch size would be smaller than in other boxes. Such a scenario would suggest that more time was given to perceived need for nest defense (Lima 1987) or to allow for increased investment in renesting (see Martin and Li 1992 and citations therein; Martin 1995, Eggers et al. 2006, Fontaine and Martin 2006). We note, too, that a smaller clutch size would contrast to effects noted by Mönkkönen et al. (2009), that can be related to the limited-breeding-opportunities hypothesis (Martin 1993). Our objectives were to examine nest initiation, clutch development, and hatching success by starlings relative to 4 nest box treatments involving both olfactory and visual cues.

\section{Methods}

\section{Study area}

We conducted our study on the 2,200 ha National Aeronautics and Space Administration Plum Brook Station (PBS), Erie County, Ohio, USA $\left(41.3721^{\circ} \mathrm{N},-82.6803^{\circ} \mathrm{W} ; 200 \mathrm{~m}\right.$ elevation), from April through June 2018, during the starling breeding season in Ohio. As noted by Tyson et al. (2011), habitat within PBS differs from the surrounding agricultural and suburban areas, and is composed of dogwood (Cornus spp.; 39\%), old field and grasslands $(31 \%)$, open woodlands $(15 \%)$, and mixed hardwood forests (11\%) interspersed with abandoned and actively used structures, and paved roads that circle and bisect the station; PBS has restricted public access (see also Bowles and Arrighi 2004).

\section{Design}

We used 120 wooden nest boxes $(28 \times 13 \times 17$ $\mathrm{cm} ; 5.1 \mathrm{~cm}$ diameter entrance). Each nest box was attached to a utility pole $2.5-3.0 \mathrm{~m}$ above the ground, protected with an aluminum predator guard below the box (Fig. 1a), and located approximately $60 \mathrm{~m}$ from the nearest box (based on the closest proximity of a neighboring utility pole, and considering semicolonial habits of the starling; Kessel 1957, Krause and Ruxton 2002). All nest boxes were fitted with a removable lid for efficient nest checks (Fig. 1b). Because of utility pole availability and location, not all boxes faced the same direction. However, previous research (Seamans et al. 2015) reported no effects of cavity entry direction on use of boxes.

Our experimental design comprised 4 treatments: novel visual cue at the entry hole, predator scent inside the next box and supplemented by a predator visual cue at the entry hole, the predator visual cue, and a novel odor inside the nest box and supplemented by the novel visual cue at the entry hole. Predator scent and novel odor treatments were placed in an equal-volume vial $(\sim 3$ $\mathrm{mL}$ ), sealed with a perforated, plastic cap, and secured within a bored, wooden block in a centerfront position, and stapled to the bottom of the nest box (Fig. 1b).

We did not include predator scent or novel odor treatments alone, nor control for the presence of the vial inside nest boxes with water alone. Our reasoning for foregoing these controls was that the 

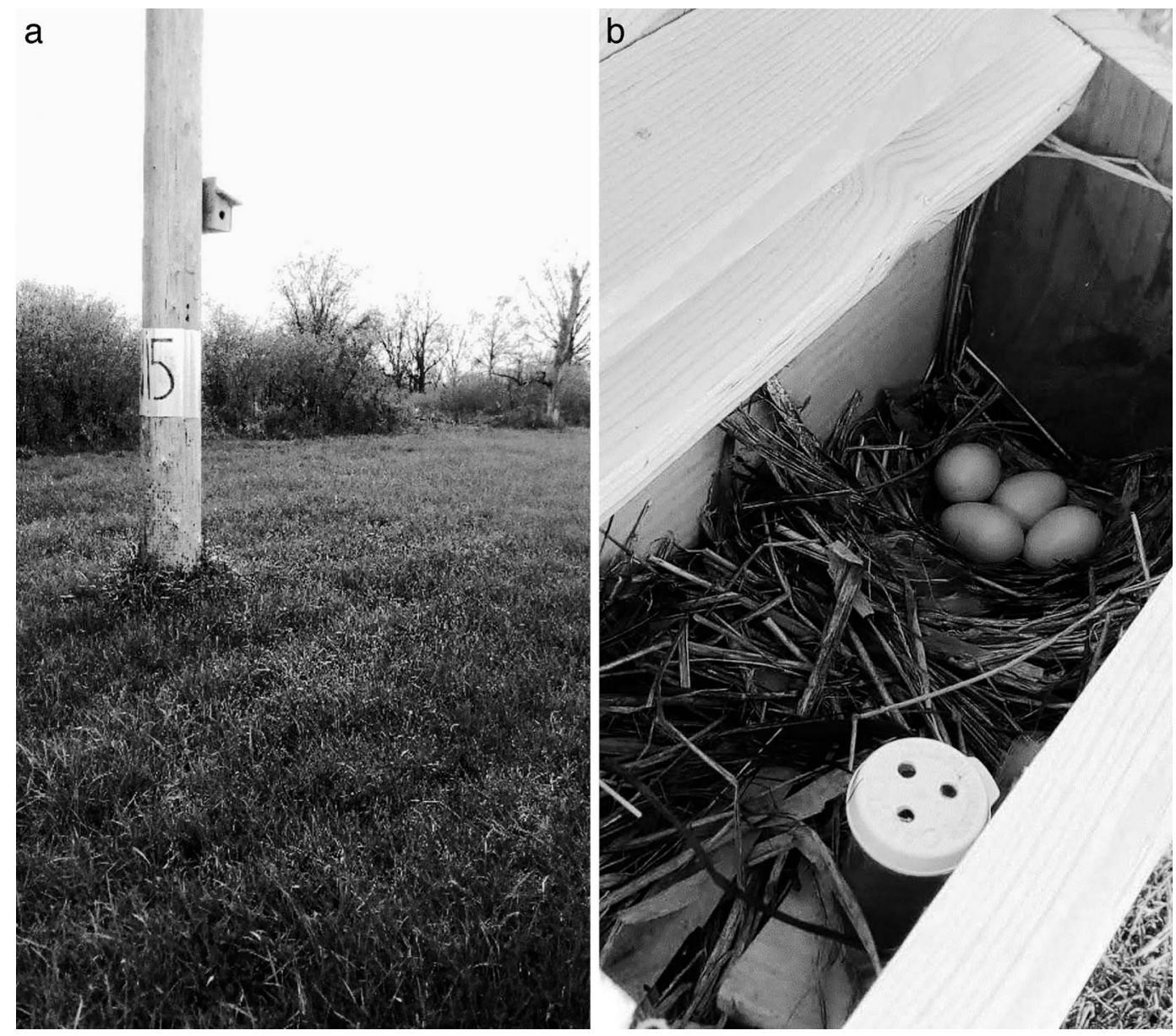

Figure 1. (taken from Blackwell et al. 2018). Example of nest box placement (a) and predator scent or novel odor treatment placement (b) used in a study of European Starling (Sturnus vulgaris) response to a novel visual cue, predator scent/predator visual cue, predator visual cue, and novel odor/novel visual cue treatments of nest boxes. A total of 120 nest boxes $(28 \times 13 \times 17 \mathrm{~cm} ; 5.1$ $\mathrm{cm}$ diameter entrance) were attached to utility poles. The study was conducted from April through June 2018, during the starling breeding season, on the U.S. National Aeronautics and Space Administration's Plum Brook facility in Erie, County, Ohio, USA. See text for further details on the study area, experimental design, and treatments. See also Fig. 2 for visual cue placement.

present study was an extension of our work at PBS the year prior (Blackwell et al. 2018), research that showed no effect on starling nesting by the 3 aforementioned treatments. In addition, an earlier study (White and Blackwell 2003) showed no effect on starling nesting by an empty vial of the same dimensions noted above, also secured inside a bored wooden block, and placed inside nest boxes. We contend, therefore, that our previous work provided justification for our decision in the present study that the 3 additional treatments were unnecessary.

We used a male raccoon urine/glandular-based product (WCS Raccoon Eviction Fluid, Wildlife
Control Supplies, East Granby, Connecticut, USA; Vantassel and Hygnstrom 2013) as the predator scent (Blackwell et al. 2018). Starling populations in North America have been exposed to raccoon predation for $\sim 120 \mathrm{yr}$ (Feare 1984; see also Hamilton 1936, Dolbeer et al. 1988, Christman and Dhondt 1997, Begg 2009), and there is evidence that experience with predation will elicit antipredator behaviors in naïve prey (Naddafi et al. 2007, Castorani and Hovel 2016). Moreover, PBS has had a historically abundant raccoon population (Blackwell et al. 2004, Ramey et al. 2008). Sitespecific exposure to particular predators, including 
witnessing predation (Moks et al. 2016), can modify antipredator sensitivity in prey species (e.g., Donselaar et al. 2018).

We controlled for the presence of a predator scent by using Febreze extra strength fabric refresher, original scent (Procter and Gamble, Cincinnati, Ohio, USA) as the novel odor (Blackwell et al. 2018). Further, we did not refill scent or novel odor treatments. However, evidence of predator scent and novel odor treatments were noticeable to humans upon removal of vials from nest boxes 2 months after the close of the Blackwell et al. (2018) study (BFB, TWS, BNB, pers. observ.). Also, as noted above, avian olfactory capabilities are complex, involving assessment of predation risk and social functions, and comparable to other vertebrates with known olfactory capabilities (Avilés and Amo 2018, and citations therein). We suggest, therefore, that predator scent and novel odor treatments were detectable by starlings in the present study during initial investigation of nest boxes and subsequent nest construction, if not longer.

We supplemented the predator scent with a predator visual cue, a tuft of raccoon hair (taken from the dorsal side of one road-killed male raccoon, and stapled to the edge of the nest box entrance hole within the perimeter of the entrance; Fig. 2a). We supplemented the novel odor with a novel visual cue, a simple ribbon (green), trimmed to an approximately equal length and area as that of the predator visual cue (Fig. 2b). However, because individual hairs composed the predator visual cue, these treatments tended to spread upon attachment to the box, and beyond the width of the ribbon treatment (Fig. 2a, b). We also recognized that the predator visual cue would likely hold some olfactory "residue" and, thus, pose possible synergistic or additive effects (e.g., Smith and Belk 2001) via visual and olfactory stimuli. However, we could not dismiss the possibility that our novel visual cue would also have some odor discernible to starlings.

We randomly assigned a treatment to our first nest box (previously numbered), which was the novel visual cue (i.e., the ribbon). We then systematically assigned a predator scent and predator visual cue treatment to box 2 , the predator visual cue to box 3 , and the novel odor and novel visual cue to box 4 . We repeated this same order of treatment assignments for each consecutive quartet
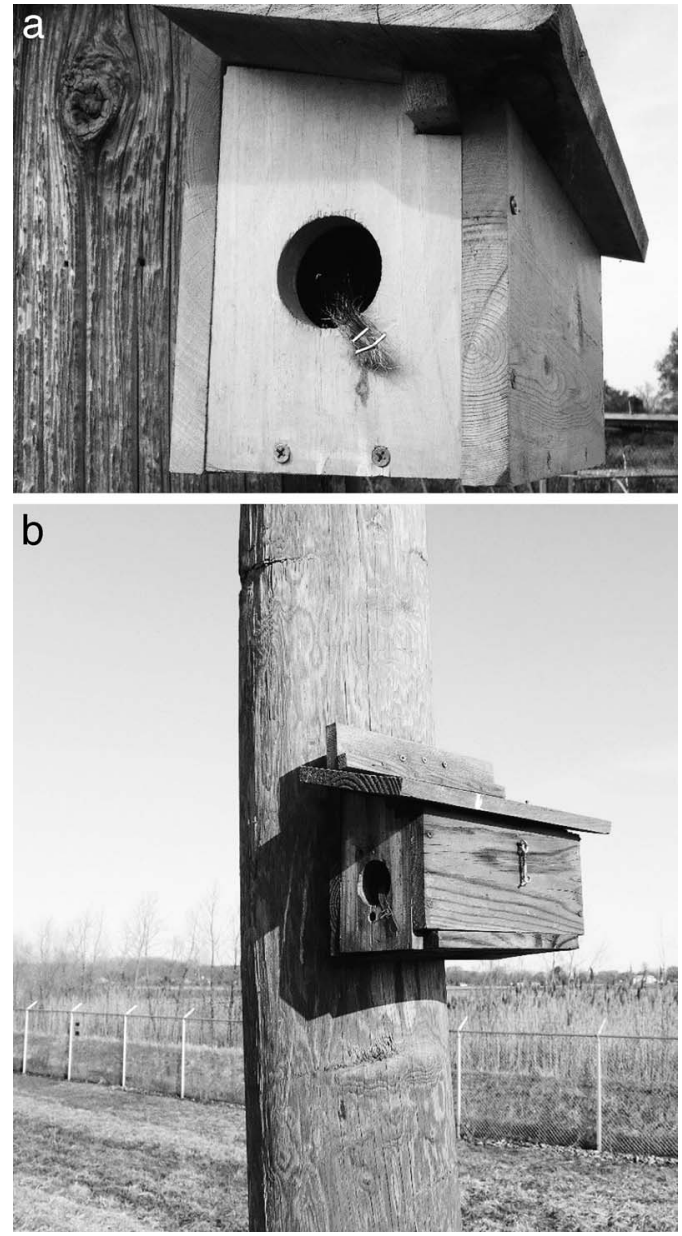

Figure 2. Example of the predator visual cue (raccoon hair; a) and novel visual cue (ribbon; b) used in a study of European Starling (Sturnus vulgaris) response to predator scent/predator visual cue, predator visual cue, novel odor/ novel visual cue, and novel visual cue treatments placed at nest boxes. A total of 120 nest boxes $(28 \times 13 \times 17 \mathrm{~cm} ; 5.1$ $\mathrm{cm}$ diameter entrance) were attached to utility poles. The study was conducted from April through June 2018, during the starling breeding season, on the U.S. National Aeronautics and Space Administration's Plum Brook facility in Erie, County, Ohio, USA. See text for further details on the study area, experimental design, and treatments.

of nest boxes to achieve a sample size of 30 nest boxes per treatment ( $n=120$ boxes).

\section{Protocol}

In northern Ohio, starlings have been found to overwinter (Kessel 1953; TWS, BFB, MBP, pers. observ.). Resident starlings overwintering on breeding grounds will begin to investigate prior 
and new, candidate nest sites during late winter through early spring (Kessel 1957). During February 2018, all remnant nesting material in nest boxes was removed and all entrances were closed. We placed treatments and opened all nest boxes on 2 April 2018, thus exposing birds to treatment upon initial investigation of the box interior and prior to a reproductive commitment at the site. We inspected each box twice weekly, beginning 5 April. Two teams of observers ( 1 or 2 observers per team) inspected nest boxes from opposite, randomly selected directions (e.g., from box 1 to 60 and box 61 to 120); these same observers collected data through completion of the study. We recorded the approximate ordinal date of first nesting material, appearance of a nest bowl (see Blackwell et al. 2018), first egg, species, maximum clutch size, maximum number of hatchlings, and hatching success (proportion of the maximum clutch size that hatched). Starlings generally lay one egg per day, begin incubation with the next-to-last or last egg laid, and incubate $\sim 12$ d; young hatch asynchronously (Feare 1984). We estimated date of first egg by subtracting the total number of eggs within a nest when first encountered from the date of the observation. We followed nests through hatching. Visual cues lost during the study (e.g., due to weather events, wear, or possibly removal by birds) were noted. We anticipated this potential problem for predator visual-cue treatments, where hair strands might be lost or removed over time. However, we did not consider a predator visual cue as lost until no strands remained. Finally, we noted whether a nest appeared to have been abandoned or to have suffered predation.

\section{Statistical analyses}

We first accounted for the possibility that predator visual cue loss affected our predatortreated nest boxes. If we assume that the predator visual cue enhanced predation risk, one would expect that nest boxes where this cue was not lost would show a later date of first egg relative to nest boxes within the same treatment, but where the cue was missing. Here, we compared date of first egg within the 2 predator treatments, respectively, via the Wilcoxon 2-sample test (PROC NPAR1WAY, SAS 9.2, SAS Institute).
Next, we evaluated the likelihood that boxes contained nesting material $14 \mathrm{~d}$ after being opened. The presence of nesting material after $14 \mathrm{~d}$ was simply an arbitrary index of how treatments might have affected starling early investigations of boxes; treatment served as the fixed effect. We used a generalized linear model, a binomial distribution, and logit link (via PROC GENMOD, SAS 9.2).

We then examined the effect of treatment on the likelihood that a nest bowl (across species) was constructed in a nest box. Here, we used a generalized linear model, a binomial distribution, and logit link. We used a general linear model (PROC GLM, SAS 9.2) to examine treatment effects on estimated date of appearance of a starling nest bowl. We examined model residuals relative to a Gaussian distribution. We also assessed treatment effects on the likelihood that a box contained a starling nest (i.e., $\geq 1$ egg), by using a generalized linear model, binomial distribution, and logit link. Finally, we evaluated treatment effects on date of first egg, maximum clutch size, maximum number of hatchlings, and hatching success via Kruskal-Wallis test applied to Wilcoxon rank sums (PROC NPAR1WAY, SAS 9.2). For all comparisons and models we set $\alpha=$ 0.05 .

\section{Results}

As anticipated, we observed disproportionate losses of visual cues on predator-treated nest boxes (novel visual cue lost, $n=3$ boxes, $\bar{x}$ days since box was opened $=2.1, \mathrm{SD}=6.5$; predator scent/ predator visual cue lost: $n=15$ boxes, $\bar{x}$ days since box was opened $=13.0, \mathrm{SD}=14.5$; predator visual cue lost, $n=11$ boxes, $\bar{x}$ days since box was opened $=8.8, \mathrm{SD}=13.2$; novel odor/novel visual cue lost $=0$ boxes). We found a difference in date of first egg, within treatment, for nest boxes treated with the predator visual cue, only. Ironically, however, starlings nested later at boxes where the predator visual cue was lost (predator visual cue loss: $\bar{x}$ date of first egg $=29.8 \mathrm{~d}$ since box opened, $\mathrm{SD}=4.2 \mathrm{~d}$; no predator visual cue loss: $\bar{x}=25.3 \mathrm{~d}$, $\mathrm{SD}=1.3 \mathrm{~d}$, Wilcoxon statistic $=101, Z=2.78, P=$ 0.006 ). Because of the progressive loss of hair strands at our boxes, we contend that this finding is not a response to predation risk wherein birds 
Table 1. Nesting metrics (SD) for European Starlings (Sturnus vulgaris) that selected nest boxes on the U.S. National Aeronautics and Space Administration's Plum Brook facility in Erie County, Ohio, USA, during April through June 2018 and relative to candidate nest-deterrent treatments. See text for details on methods and treatments used.

\begin{tabular}{lccccccc}
\hline \multicolumn{1}{c}{ Treatment } & $\begin{array}{c}\text { Days since } \\
\text { box opened for } \\
\text { 1st nesting material }\end{array}$ & $\begin{array}{c}\text { Days since } \\
\text { box opened } \\
\text { for nest bowl }\end{array}$ & $\begin{array}{c}\text { No. nests } \\
\text { with } \\
\geq 1 \text { egg }\end{array}$ & $\begin{array}{c}\text { Days since } \\
\text { box opened for } \\
\text { 1st egg }\end{array}$ & $\begin{array}{c}\text { Max. } \\
\text { clutch }\end{array}$ & $\begin{array}{c}\text { Max. } \\
\text { hatchlings }\end{array}$ & $\begin{array}{c}\text { Hatching } \\
\text { success }\end{array}$ \\
\hline Novel visual cue & $6.1(3.5)$ & $24.5(6.9)$ & $22^{\mathrm{a}}$ & $29.0(5.3)$ & $4.6(1.4)$ & $3.4(2.2)$ & $0.67(0.42)$ \\
Predator scent/predator visual cue & $7.2(3.7)$ & $22.5(4.6)$ & $20^{\mathrm{a}}$ & $25.8(2.5)$ & $4.8(1.2)$ & $4.3(1.8)$ & $0.83(0.31)$ \\
Predator visual cue & $8.3(3.3)$ & $24.7(3.3)$ & 17 & $27.4(3.7)$ & $4.5(0.8)$ & $3.8(1.8)$ & $0.80(0.33)$ \\
Novel odor/novel visual cue & $7.4(3.2)$ & $26.2(6.9)$ & 21 & $28.9(5.5)$ & $4.6(1.3)$ & $3.4(2.0)$ & $0.69(0.41)$ \\
\hline
\end{tabular}

${ }^{\text {a }}$ One nest box did not contain a nest bowl, but a single egg was observed, likely due to egg dumping. See text.

nested earlier, as noted by Mönkkönen et al. (2009). For example, for nest boxes treated with predator scent and predator visual cue, we found no difference in date of first egg relative to loss of the visual cue (boxes with predator visual cue loss: $\bar{x}=25.0 \mathrm{~d}$ since box opened, $\mathrm{SD}=1.7 \mathrm{~d}$; no predator visual cue loss: $\bar{x}=26.5 \mathrm{~d}, \mathrm{SD}=2.9 \mathrm{~d}$, Wilcoxon statistic $=79, Z=-1.20, P=0.231$ ).

We found no difference across treatments in the presence of nest material after boxes had been opened for $14 \mathrm{~d}$ ( $n=95$ boxes; novel visual cue $=$ 21 boxes, predator scent/predator visual cue $=25$ boxes, predator visual cue $=24$ boxes, novel odor/ novel visual cue $=25$ boxes; Likelihood Ratio Statistics for Type III analysis: $\chi^{2}=2.07, \mathrm{df}=3, P$ $=0.557$; Table 1). Further, there was no difference across treatments in likelihood of a nest bowl $(n=$ 105 boxes; novel visual cue $=26$ boxes, predator scent/predator visual cue $=26$ boxes, predator visual cue $=25$ boxes, novel odor/novel visual cue $=28$ boxes; Likelihood Ratio Statistics for Type III analysis: $\left.\chi^{2}=3.53, \mathrm{df}=3, P=0.317\right)$, nor in date of appearance of a starling nest bowl $(n=78$ boxes with nest bowls; novel visual cue $=21$ boxes, predator scent/predator visual cue $=19$ boxes, predator visual cue $=17$ boxes, novel odor/novel visual cue $=21$ boxes; $F_{3,74}=1.20, P=0.315$; Table 1). Also, we found no difference across treatments in the likelihood that starlings would complete a nest (i.e., clutch of $\geq 1$ egg; Likelihood Ratio Statistics for Type III Analysis: $n=80$ boxes, $\chi^{2}=2.5, \mathrm{df}=3, P=0.474$; Table 1).

Although starlings laid eggs in 80 nest boxes (67\% of nest available boxes), in 2 boxes we found only a single egg, respectively, but never observed a completed nest; we suspect that these eggs were dumped (Kessel 1957, Power et al. 1981, Evans 1988; Table 1). In addition, we found no treatment effect on date of first egg (KruskalWallis test on Wilcoxon Rank Sums: $\chi^{2}=5.3, \mathrm{df}=$ $3, P=0.152)$, maximum clutch size $\left(\chi^{2}=2.3, P=\right.$ $0.512)$, or maximum hatchlings $\left(\chi^{2}=2.6, P=\right.$ 0.456 ). Interestingly, we observed that 13 clutches were abandoned, predominantly in nest boxes treated with novel cues (novel odor/novel visual cue: 5 boxes; novel visual cue: 5 boxes; predator scent/predator visual cue: 2 boxes; predator visual cue: 1 box). However, we found no treatment effect on hatching success $\left(\chi^{2}=2.3, P=0.509\right.$; Table 1).

Other species using nest boxes (generally beginning nesting later than starlings) included the Eastern Bluebird (Sialia sialis; $n=2$ boxes), House Wren (Troglodytes aedon; $n=1$ box), Tree Swallow (Tachycineta bicolor; $n=10$ boxes), and southern flying squirrel (Glaucomys volans; $n=1$ box); 26 nest boxes (22\%) went unused.

\section{Discussion}

In an extension of an earlier study examining indirect predation risk to European Starlings using nest boxes (Blackwell et al. 2018), we found that starlings were not dissuaded from nesting in nest boxes defended by predator scent inside the box and supplemented by a predator visual cue at the entrance hole. We observed no treatment effects on deposition of nesting material, appearance of a nest bowl, establishment of a starling nest, or reproduction. Moreover, birds were depositing nest material within approximately $9 \mathrm{~d}$ after the nest boxes were opened. Clearly, if the combination of predator scent and predator visual cue enhanced perceived risk, enhancement was brief at best, or antipredator responses (e.g., increased vigilance; unmeasured) compensated. We consider 
several non-mutually exclusive explanations for the starling response.

First, as we noted in our previous research (Blackwell et al. 2018), indirect cues associated with the raccoon, a unique predator from an evolutionary perspective, might go unrecognized by the starling. However, we also argued that there is reason to suspect adequate antipredator responses from both the perspectives of evolutionary evidence (see phylogeny of Canoidea; MacClintock 1981; predator archetypes; Cox and Lima 2006, Carthey and Blumstein 2018) and recent predation history (Hamilton 1936, Dolbeer et al. 1988, Christman and Dhondt 1997, Begg 2009; see also raccoon predation on adult cavity-nesting birds Kilham 1971). In addition, we previously noted that starlings are likely well adapted to responding to native North American nest predators, wherein such plasticity in antipredator behavior might have served invasion success (Castorani and Hovel 2016, Hudson et al. 2017, Carthey and Blumstein 2018).

Alternatively, a limited number of available nest sites could have resulted in the lack of avoidance of predator-treated nest boxes. For example, Stanback et al. (2018) showed that a visual predator cue on nest boxes failed to deter nesting by Eastern Bluebirds, and suggested that cavity resources for secondary cavity nesters were limited (see also Godard et al. 2007, Johnson et al. 2011). In our study, however, only $67 \%$ of nest boxes were used by starlings (versus $57 \%$ reported by Blackwell et al. 2018). Given tree cover on PBS (Tyson et al. 2011), natural cavities on the research site were likely not limited (Seamans et al. 2015, Pfeiffer et al. 2019).

A more plausible explanation for the lack of effect by our predator treatments centers on both experience with predation attempts and plasticity in antipredator responses. Specifically, behavioral plasticity in response to predation is influenced by prior experience with predators (Barnett 1982, Curio 1988, Griffin et al. 2001, Brown et al. 2013, Chivers et al. 2014). Further, perceived risk associated with direct and indirect experience of nest predation serves as a selective force in birds, influencing nest types and concealment, mating behaviors, and reproductive behavior and physiology (e.g., Ricklefs 1969, 1977; Slagsvold 1982, Lima 1987, Martin 1988, 1993, 1995; Lima 2009, Martin and Briskie 2009). As noted earlier, the placement of predator guards below nest boxes, while preventing undue interruption of our study due to nest predation, might have reduced sensitivity of breeding starlings to direct predation risk from raccoons, if they had nested in nest boxes on PBS during the previous year (see Godard et al. 2007), or indirect risk via witnessing predation events on neighboring nest boxes (Moks et al. 2016). That said, starling witness to raccoon predation on natural cavities was quite possible given the mix of old field, managed turf grass, and timbered areas on PBS (Tyson et al. 2011). Ultimately, however, starling response to perceived predation risk might follow according to predator type and frequency of encounter (Lima and Dill 1990, Lima 2009; see also Stanback et al. 2019). For example, pygmy salamanders (Desmognathus wrighti) adjust activity patterns to maximize resource acquisition under chronic predation, whereby individuals tolerate moderate risk, but avoid less common, yet more specialized predators, or unfamiliar species (Forester et al. 2019). As noted earlier, raccoons are not uncommon on PBS (Blackwell et al. 2004, Ramey et al. 2008), but successful predation on protected nest boxes is rare.

In conclusion, we observed no effects on starling timing of nest initiation or reproduction by exposure to raccoon scent inside nest boxes and supplemented with a visual cue composed of raccoon hair attached below the entry hole. The approximately $17 \%$ of novel cue nest boxes that experienced abandonment might be due, in part, to the effect of the ribbon treatment partially protruding across the lower portion of the entry hole (e.g., Peterson and Gauthier 1985). However, in all but 2 of these sites (where we suspect that an egg was dumped), we observed a nest bowl and clutch. We note that predator visual-cue treatments also protruded across the lower portion of the entry hole, but weather conditions and bird passage often pushed these treatments down below the hole.

Because the indirect predator cues that we investigated were ineffective in deterring starling nesting, we suggest that future research evaluate the role of a predator effigy (e.g., a small snake; Parejo and Avilés 2011, Stanback et al. 2018) and animacy (Greggor et al. 2018). Specifically, we recommend that the effigy be placed inside nest boxes. In addition, we suggest that researchers 
consider the potential for enhancing perceived nest predation risk (Eggers et al. 2006) to starlings in foraging areas within $100 \mathrm{~m}$ of nest boxes (Heldbjerg et al. 2017).

\section{Acknowledgments}

Our methods for this study were approved by the U.S. Department of Agriculture, National Wildlife Research Center Institutional Animal Care and Use Committee under protocol 2911.

We thank CA Davis, JD Cepek, and TL DeVault for their comments on an earlier version of this manuscript. Author (BFB, TWS, and BNB) and research support was provided by the intramural research program of the U.S. Department of Agriculture, Animal and Plant Health Inspection Service, Wildlife Services, National Wildlife Research Center. The U.S. Federal Aviation Administration (FAA) provided support for MBP. Research findings herein do not necessarily reflect FAA policy regarding wildlife management on airports.

\section{Literature cited}

Aitken KE, Martin K. 2008. Resource selection plasticity and community responses to experimental reduction of a critical resource. Ecology 89:971-980.

Amo L, Galván I, Tomás G, Sanz JJ. 2008. Predator odour recognition and avoidance in a songbird. Functional Ecology 22:289-293.

Amo L, Tomás G, López-García A. 2017. Role of chemical and visual cues of mammalian predators in nest defense in birds. Behavioral Ecology and Sociobiology 71:49. doi:10.1007/s00265-017-2281-9

Amo L, Visser ME, van Oers K. 2011. Smelling out predators is innate in birds. Ardea 99:177-184.

Apfelbach R, Blanchard CD, Blanchard RJ, Hayes RA, McGregor IS. 2005. The effects of predator odors in mammalian prey species: A review of field and laboratory studies. Neuroscience \& Biobehavioral Reviews 29:1123-1144.

Avilés JM, Amo L. 2018. The evolution of olfactory capabilities in wild birds: A comparative study. Evolutionary Biology 45:27-36.

Barnett C. 1982. The chemosensory responses of young cichlid fish to parents and predators. Animal Behaviour $30: 35-42$.

Begg B. 2009. Northern raccoon predation on European Starling nestlings in British Columbia. Wildlife Afield 6(1):25-26.

Blackwell BF, Seamans TW, Pfeffer MB, Buckingham BN. 2018. European Starling (Sturnus vulgaris) reproduction undeterred by predator scent inside nest boxes. Canadian Journal of Zoology 96:980-986.

Blackwell BF, Seamans TW, White RJ, Patton ZJ, Bush RM, Cepek JD. 2004. Exposure time of oral rabies vaccine baits relative to baiting density and raccoon population density. Journal of Wildlife Diseases 40:222-229.

Bowles MD, Arrighi RS. 2004. NASA's nuclear frontier: The Plum Brook reactor facility. Monographs in aerospace history, vol. 33. Washington (DC): NASA Headquarters, Office of External Relations, NASA History Division.

Bridgman CJ. 1962. Bird nesting in aircraft. Breeding Birds 55:461-470.

Brown GE, Ferrari MCO, Elvidge CK, Ramnarine I, Chivers DP. 2013. Phenotypically plastic neophobia: A response to variable predation risk. Proceedings of the Royal Society B 280:20122712. doi:10.1098/rspb. 2012.2712

Brush T. 1983. Cavity use by secondary cavity-nesting birds and response to manipulations. Condor 85:461-466.

Cabe PR. 1993. European Starling (Sturnus vulgaris), version 2.0. In: Poole A, editor. Birds of North America. Ithaca (NY): Cornell Lab of Ornithology.

Carthey AJR, Blumstein DT. 2018. Predicting predator recognition in a changing world. Trends in Ecology \& Evolution 33:106-115.

Castorani MCN, Hovel KA. 2016. Native predator chemical cues induce anti-predation behaviors in an invasive marine bivalve. Biological Invasions 18:169-181.

Chapman FM. 1925. The European Starling as an American citizen. Natural History 25:480-485.

Chivers DP, McCormick MI, Mitchell MD, Ramasamy RA, Ferrari MCO. 2014. Background level of risk determines how prey categorize predators and non-predators. Proceedings of the Royal Society B. 281:20140355. doi:10.1098/rspb.2014.0355

Christman BJ, Dhondt AA. 1997. Nest predation in Blackcapped Chickadees: How safe are cavity nests? Auk 114:769-773.

Clark L, Mason JR. 1987. Olfactory discrimination of plant volatiles by the European Starling. Animal Behaviour 35:227-235.

Cox JG, Lima SL. 2006. Naiveté and an aquatic-terrestrial dichotomy in the effects of introduced predators. Trends in Ecology \& Evolution 21:674-680.

Crick HQ, Robinson RA, Appleton GF, Clark NA, Rickard AD. 2002. Investigation into the causes of the decline of Starlings and House Sparrows in Great Britain. British Trust for Ornithology Research Report 290:1305.

Curio E. 1988. Cultural transmission of enemy recognition by birds. In: Zentall TR, Galef BG Jr, editors. Social learning: Psychological and biological perspectives. Hillsdale (NJ): Lawrence Erlbaum Associates; p. 7597.

DeGroof G, Gwinner H, Steiger S, Van der Kempenaers B, Linden A. 2010. Neural correlates of behavioural olfactory sensitivity changes seasonally in European Starlings. PLOS One 5:e14337. doi:10.1371/journal. pone

DeVault TL, Belant JL, Blackwell BF, Seamans TW. 2011. Interspecific variation in wildlife hazards to aircraft: Implications for airport wildlife management. Wildlife Society Bulletin 35:394-402.

DeVault TL, Blackwell BF, Seamans TW, Begier MJ, Kougher JD, et al. 2018. Estimating interspecific economic risk of bird strikes with aircraft. Wildlife Society Bulletin 42:94-101.

Dolbeer RA, Begier MJ. 2019. Wildlife strikes to civil aircraft in the United States 1990-2017. Washington (DC): US Department of Transportation, Federal 
Aviation Administration, Office of Airport Safety and Standards, Serial Report 24.

Dolbeer RA, Link MA, Woronecki PP. 1988. Naphthalene shows no repellency for starlings. Wildlife Society Bulletin 16:62-64.

Donselaar JL, Atma JL, Kruyf ZA, Croix HN, Darren SP. 2018. Urbanization alters fear behavior in Blackcapped Chickadees. Urban Ecosystems 21:1043-1051.

Eggers S, Griesser M, Nystrand M, Ekman J. 2006. Predation risk induces changes in nest-site selection and clutch size in the Siberian Jay. Proceedings of the Royal Society B 273:701-706.

Evans PGH. 1988. Intraspecific nest parasitism in the European Starling Sturnus vulgaris. Animal Behaviour 36:1282-1294.

Feare C. 1984. The starling. New York (NY): Oxford University Press.

Fontaine JJ, Martel M, Markland HM, Niklison AM, Decker KL, Martin TE. 2007. Testing ecological and behavioral correlates of nest predation. Oikos 116:18871894.

Fontaine JJ, Martin TE. 2006. Parent birds assess nest predation risk and adjust their reproductive strategies. Ecological Letters 9:428-434.

Forester JD, Frester DC, Matkowski JM. 2019. Making the best of a bad situation: Differential predator avoidance in a diminutive woodland salamander. Animal Behaviour 148:169-181.

Forsman JT, Mönkkönen M, Korpimäki E, Thomson RL. 2013. Mammalian nest predator feces as a cue in avian habitat selection decisions. Behavioral Ecology 24:262-266.

Godard RD, Bowers BB, Wilson CM. 2007. Eastern Bluebirds Sialia sialis do not avoid nest boxes with chemical cues from two common nest predators. Journal of Avian Biology 38:128-131.

Greggor AL, McIvor GE, Clayton NS, Thornton A. 2018. Wild jackdaws are wary of objects that violate expectations of animacy. Open Science 5:181070.

Griffin AS, Evans CS, Blumstein DT. 2001. Learning specificity in acquired predator recognition. Animal Behaviour 62:577-589.

Hamilton WJ Jr. 1936. The food and breeding habits of the raccoon. Ohio Journal of Science 36:131-140.

Hegab IM, Kong S, Yang S, Mohamaden WL, Wei W. 2015. The ethological relevance of predator odors to induce changes in prey species. Acta Ethologica 18:1-9.

Heldbjerg H, Fox AD, Thellesen PV, Dalby L, Sunde P. 2017. Common Starlings (Sturnus vulgaris) increasingly select for grazed areas with increasing distanceto-nest. PLOS One 12:e0182504.

Hua F, Fletcher RJ Jr, Sieving KE, Dorazio RM. 2013. Too risky to settle: Avian community structure changes in response to perceived predation risk on adults and offspring. Proceedings of the Royal Society B 280:20130762. doi:10.1098/rspb.2013.0762

Hua F, Sieving KE, Fletcher RJ Jr, Wright CA. 2014. Increased perception of predation risk to adults and offspring alters avian reproductive strategy and performance. Behavioral Ecology 25:509-519.

Hudson CM, Brown GP, Shine R. 2017. Evolutionary shifts in anti-predator responses of invasive cane toads
(Rhinella marina). Behavioral Ecology and Sociobiology $71: 134$.

Ingold D. 1994. Influence of nest-site competition between European Starlings and woodpeckers. Wilson Bulletin 106:227-241.

Jackson JA. 2000. Rapid nest-site selection and initiation of nests on commercial aircraft by European Starlings. Migrant 71:97-99.

Johnson LS, Murphy SM, Parrish GW. 2011. Lack of predator-odor detection and avoidance by a songbird, the House Wren. Journal of Field Ornithology 82:150 157.

Kalmbach ER, Gabrielson IN. 1921. Economic value of the European Starling in the United States. Bulletin of the U.S. Department of Agriculture, No. 868.

Kats LB, Dill LM. 1998. The scent of death: Chemosensory assessment of predation risk by prey animals. Ecoscience 5:361-394.

Kerpez TA, Smith NS. 1990. Competition between European Starlings and native woodpeckers for nest cavities in saguaros. Auk 107:367-375.

Kessel B. 1953. Second broods in the European Starling in North America. Auk 70:479-483.

Kessel B. 1957. A study of the breeding biology of the European Starling (Sturnus vulgaris L.) in North America. American Midland Naturalist 58:257-331.

Kilham L. 1971. Reproductive behavior of Yellow-bellied Sapsuckers. I. Preference for nesting in Fomes-infected aspens and nest hole interrelations with flying squirrels, raccoons, and other animals. Wilson Bulletin 83:159171.

Koenig WD. 2003. European Starlings and their effect on native cavity-nesting birds. Conservation Biology 17:1134-1140.

Koenig WD, Walters EL, Rodewald PG. 2017. Testing alternative hypotheses for the cause of population declines: The case of the Red-headed Woodpecker. Condor 119:143-154.

Krause J, Ruxton GD. 2002. Living in groups. Oxford (UK): Oxford University Press.

Lewis RJ, Conover MR. 2018. Feeding a hungry world. In: Pitt WC, editor. Ecology and management of terrestrial vertebrate invasive species in the United States. Boca Raton (FL): Taylor \& Francis; p. 99-105.

Lima SL. 1987. Clutch size in birds: A predation perspective. Ecology 68:1062-1070.

Lima SL. 1998. Nonlethal effects in the ecology of predator-prey interactions. BioScience 48:25-34.

Lima SL. 2009. Predators and the breeding bird: Behavioral and reproductive flexibility under the risk of predation. Biological Reviews of the Cambridge Philosophical Society $84: 485-513$.

Lima SL, Bednekoff PA. 1999. Temporal variation in danger drives antipredator behavior: The predation risk allocation hypothesis. American Naturalist 153:649659.

Lima SL, Dill LM. 1990. Behavioral decisions made under the risk of predation: A review and prospectus. Canadian Journal of Zoology 68:619-640.

Linz GM, Homan JH, Gaukler SM, Penry LB, Bleier WJ. 2007. European Starlings: A review of an invasive species with far-reaching impacts. In: Witmer GW, Pitt WC, Fagerstone KA, editors. Symposium 24. Manag- 
ing Vertebrate Invasive Species. Fort Collins (CO): National Wildlife Research Center; p. 378-386.

Lloyd R, Alford RA, Schwarzkopf L. 2009. Chemical discrimination among predators by lizards: Responses of three skink species to the odours of high- and lowthreat varanid predators. Austral Ecology 34:50-54.

Lodge DM. 1993. Biological invasions: Lessons for ecology. Trends in Ecology \& Evolution 8:133-136.

Lowry H, Lill A, Wong BBM. 2013. Behavioural responses of wildlife to urban environments. Biological Reviews 88:537-549.

MacClintock D. 1981. A natural history of raccoons. New York (NY): Charles Scribner's Sons.

Martin TE. 1988. Habitat and area effects on forest bird assemblages: Is nest predation an influence? Ecology 69:4-84.

Martin TE. 1993. Nest predation and nest sites: New perspectives on old patterns. BioScience 43:523-532.

Martin TE. 1995. Avian life history evolution in relation to nest sites, nest predation, and food. Ecological Monographs 65:101-127.

Martin TE, Briskie JV. 2009. Predation on dependent offspring: A review of the consequences for mean expression and phenotypic plasticity in avian life history traits. Annals of the New York Academy of Sciences 1168:201-217.

Martin TE, Li P. 1992. Life history traits of open- vs. cavitynesting birds. Ecology 73:579-592.

Mennechez G, Clergeau P. 2006. Effect of urbanisation on habitat generalists: Starlings not so flexible? Acta Oecologica 30:182-191.

Moks K, Tilgar V, Thompson RL, Calhim S, Järvistö PE, et al. 2016. Predator encounters have spatially extensive impacts on parental behaviour in a breeding bird community. Proceedings of the Royal Society B 283:20160020.

Mönkkönen M, Forsman JT, Kananoja T, Ylönen H. 2009. Indirect cues of nest predation risk and avian reproductive decisions. Biology Letters 5:176-178.

Mouton JC, Martin TE. 2018. Fitness consequences of interspecific nesting associations among cavity-nesting birds. American Naturalist 192:389-396.

Naddafi R, Eklöv P, Pettersson K. 2007. Non-lethal predator effects on the feeding rate and prey selection of the exotic zebra mussel Dreissena polymorpha. Oikos 116:1289-1298.

Nice MM. 1957. Nesting success in altricial birds. Auk 74:305-321.

Parejo D, Avilés JM. 2011. Predation risk determines breeding territory choice in a Mediterranean cavitynesting bird community. Oecologia 165:185-191.

Parsons MH, Blumstein DT. 2010. Familiarity breeds contempt: Kangaroos persistently avoid areas with experimentally deployed dingo scents. PLOS One 5:e10403.

Pimentel D, Lach L, Zuniga R, Morrison D. 2000. Environmental and economic costs of nonindigenous species in the United States. BioScience 50:53-65.

Pérez JH. 1988. Estornino pinto el la capital federal [Painted Starling in the federal capital]. Nuestra Aves 17:13.
Peterson B, Gauthier G. 1985. Nest site use by cavitynesting birds of the Cariboo Parkland, British Columbia. Wilson Bulletin 97:319-331.

Pfeiffer MB, Seamans TW, Buckingham BN, Blackwell BF. 2019. Landscape factors that influence European Starling (Sturnus vulgaris) nest box occupancy in northern Ohio. Ohio Journal of Science 119:38-47.

Power HW, Litovich E, Lombardo MP. 1981. Male starlings delay incubation to avoid being cuckolded. Auk 98:386-389.

Ramey PC, Blackwell BF, Gates RJ, Slemons RD. 2008. Efficacy of oral rabies vaccination of a northern Ohio raccoon population: Relevance of population density and pre-bait serology. Journal of Wildlife Diseases 44:553-568.

Ricklefs RE. 1969. An analysis of nesting mortality in birds. Smithsonian Contributions to Zoology 9:1-48.

Ricklefs RE. 1977. Reactions of some Panamanian birds to human intrusion at the nest. Condor 79:376-379.

Roth TC II, Cox JG, Lima SL. 2008. Can foraging birds assess predation risk by scent? Animal Behaviour 76:2021-2027.

Seamans TW, Blackwell BF, Tyson LA. 2015. Low occupancy rates of artificial nest cavities by European Starlings. Ohio Journal of Science 115:53-55.

Sih A, Bell AM, Johnson JC, Ziemba RE. 2004. Behavioral syndromes: An integrative overview. Quarterly Review of Biology 79:241-277.

Slagsvold T. 1982. Clutch size variation in passerine birds: The nest predation hypothesis. Oecologia 54:159-169.

Smith ME, Belk MC. 2001. Risk assessment in the western mosquitofish (Gambusia affinis): Do multiple cues have additive effects? Behavioral Ecology and Sociobiology 51:101-107.

Stanback MT, DiLuzio NA, Mercadante AN, Diamant ES. 2018. Eastern Bluebirds (Sialia sialis) do not abandon their chosen nest site in response to a single visit by a nest predator. Wilson Journal of Ornithology 130:568-573.

Stanback MT, Dove CM, Fonda C, Parks P, Ptaschinski J. 2019. Eastern Bluebirds (Sialia sialis) do not avoid nest cavities containing predator odors. Wilson Journal of Ornithology 131:680-686.

Stanbury M, Briskie JV. 2015. I smell a rat: Can New Zealand birds recognize the odor of an invasive mammalian predator? Current Zoology 61:34-41.

Tyson LA, Blackwell BF, Seamans TW. 2011. Artificial nest cavity used successfully by native species and avoided by European Starlings. Wilson Journal of Ornithology 123:827-830.

Vantassel SM, Hygnstrom SE. 2013. Efficacy of two raccoon eviction fluids. Proceedings of the Wildlife Damage Management Conference 15:108-112.

White RJ, Blackwell BF. 2003. Ineffectiveness of sulfurbased odors as nesting deterrents against European Starlings. Ohio Journal of Science 103:126-128.

Winterbottom J, Liversidge R. 1954. The European Starling in the south west Cape. Ostrich 25:89-96.

Zufiaurre E, Abba A, Bilenca D, Codesido M. 2016. Role of landscape elements on recent distributional expansion of European Starlings (Sturnus vulgaris) in agroecosystems of the Pampas, Argentina. Wilson Journal of Ornithology 128:306-313. 